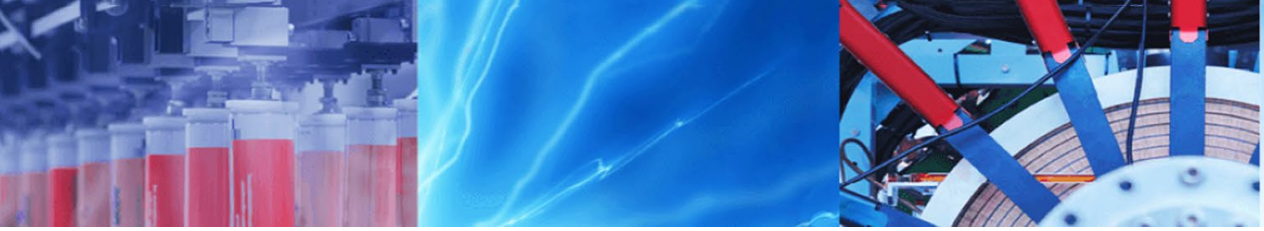

Research Article

\title{
The combined effect of using recycled coarse aggregate and well water on normal concrete
}

\author{
Roua Suhail Zidan ${ }^{1} \cdot$ Tuqa Waled Ahmed $^{1} \cdot$ Ahmed A. Mohammed Ali $^{1}$ (D)
}

(c) Springer Nature Switzerland AG 2019

\begin{abstract}
The reuse of materials from destroyed structures as recycled aggregate for concrete has become an important issue, especially in Iraq's Mosul City following the war of 2017. Many water types which are unacceptable for drinking, such as the well water available in Mosul, may be used in concrete, avoiding the need to use precious potable water. In this study, the effects of non-potable well water and recycled coarse aggregate on the mechanical properties of normal concrete (compressive, splitting, and flexural strength) and the effects of using well water on the compressive strength of mortar were investigated. Several concrete mixes were prepared: a reference mix using natural coarse aggregate and potable water, mixes using recycled coarse aggregate with and without well water, and one using natural coarse aggregate and well water. The concrete specimens were cured and tested for compressive, splitting, and flexural strengths with both types of water (well and potable) used as mixing and curing water. The compressive strength of concrete was lower by about $7.5 \%$ when well water was used with natural coarse aggregate; approximately, a $19 \%$ decrease in compressive strength was observed when recycled coarse aggregate was used with well water. The flexural and splitting tensile strengths also decreased with well water, while the values of these properties increased when recycled coarse aggregate was used.
\end{abstract}

Keywords Compressive strength $\cdot$ Potable water $\cdot$ Recycled aggregate concrete $\cdot$ Well water

\section{Introduction}

\subsection{Recycled aggregate concrete}

Concrete is a commonly used construction material all over the world [1]. To move toward a more financially and ecologically sustainable economy, waste materials should be progressively considered for secondary uses, such as preparing concrete. However, for that purpose, industrial processes for the sustainable use of such materials should also be identified [2].

Huge amounts of waste materials accumulated from buildings destroyed during the 2017 war in Mosul City, Iraq, because these materials are non-biodegradable and will remain for the next many years; this represents a real pollution problem. One way to reuse these materials is to use them to partially or fully replace natural aggregate to produce new concrete. The reuse of these materials is accomplished by crushing the clean parts that do not include reinforcing bars or pieces of plastics or wood to gravel and then separating this gravel by sieves to different sizes. This option provides a good source of concrete aggregates, recycled aggregate (RA), and recycled concrete aggregate (RCA) from construction and demolition waste (CDW).

The use of CDW in place of natural coarse aggregate in construction began after the Second World War [3]. Early recycling of building waste took place in Germany at that time to make use of the large numbers of war-devastated buildings while also creating materials for new construction [4]. At that time, Gluzhge was interested in the use of recycled aggregate and found that the reuse of destroyed

Ahmed A. Mohammed Ali, a.aldubony@uomosul.edu.iq | ${ }^{2}$ Civil Engineering Department, College of Engineering, University of Mosul, Mosul, Iraq.

SN Applied Sciences (2019) 1:927 | https://doi.org/10.1007/s42452-019-0962-x

Received: 6 April 2019 / Accepted: 20 July 2019 / Published online: 27 July 2019

SN Applied Sciences

A SPRINGer NATURE journal 
buildings helps reduce the cost of transporting natural aggregates from their sources to construction sites, as well as addressing the need to dispose of destroyed building materials and reducing the need for landfill space $[5,6]$.

In a more recent work, Rifat et al. studied the possibility of using recycled aggregate as an alternative in the concrete mixes and pavements' constructions. They used recycled aggregate as a fine aggregate in addition to the normal sand; their tests showed that the recycled aggregate concrete gives acceptable results for concrete mixes and the base layer in roads [7]. Al-Sulayfani et al. made a number of concrete mixes; after studying their mechanical properties, they crushed them and reused them as coarse aggregate in new concrete mixes to study the mechanical properties of those new mixes. The results showed the possibility of using recycled destroyed concrete as aggregates. Also, the results showed a decrease in compressive strength and an increase in tensile strength. They provided a mix design procedure for the future design of any mix using crushed recycled concrete as an aggregate [8]. Sheen et al. [9] used construction waste generated by the Chi-Chi Taiwan earthquake and concluded that the high water absorption negatively affects the strength of the recycled aggregate concrete and that the use of fine ingredients decreases its compressive strength. Ramadevi and Chitra [10] used recycled aggregate in concrete mix with $\mathrm{M} 25$ proportion; the replacement of recycled aggregate with the natural coarse aggregate was in $0 \%, 30 \%$, $60 \%$, and $100 \%$ proportions; the results show increasing compressive strength, but the flexural and splitting tensile strengths were found to be approximately equal to those of natural coarse aggregate.

\subsection{Non-potable well water}

In concrete technology, water is used for mixing, curing, and washing concrete equipment and aggregates. The type of water used, as well as the quantity, is essential in determining the quality of the hardened concrete [11]. Potable water can be replaced by many sources of water for concrete manufacturing and in the process of concrete production operations.

These types comprise groundwater, reclaimed water, and treated water from sewers or mining [12]. The difficulties in finding potable water in some places, the rising costs of such water, and the availability of bore wells of non-potable water have encouraged research about the properties of concrete prepared with non-potable water. Ghorab [13] submitted the requirements of water corresponding to EN 206-1 adequate for concrete making and explained methods to determine its suitability. Neville [14] showed that when drinking water containing high concentrations of sodium and potassium is used to prepare concrete, dangerous reactions between alkali and aggregate may occur, rendering it unsuitable for use as mixing water, though potable water is generally safe for this purpose. Al-Amoudi studied the effect of sulfates in the groundwater on cement mortar with silica fume at 10 , and $20 \%$ and $\mathrm{w} / \mathrm{c}(0.35)$ infused in water with $2.1 \% \mathrm{SO}_{4}$ for 360 days. The results showed that for equal concentrations of $\mathrm{MgSO}_{4}$ and $\mathrm{NaSO}_{4}, \mathrm{MgSO}_{4}$ would be less aggressive than $\mathrm{NaSO}_{4}$ in prolongation, but more aggressive in its effects on compressive strength [15]. Hassan et al. studied the possibility of using the well water (taken from three different places in Mosul) in the production of concrete mixes with ordinary and sulfate-resistant Portland cement. When compared with control mixes (made with distilled water), the results showed that well water within acceptable chemical analysis limits was suitable for concrete production [16]. Kucche et al. produced a review paper discussing the quality of water required for producing concrete, illustrating the admissible outlines of chemical and physical impurities and ideas to test their development. Their work shows that the time of setting is affected by factors of water-cement reaction, concrete softening, and compressive strength [17].

\subsection{Significance}

Given the considerable number of destroyed buildings in Mosul and the wide use of well water there, we sought to study the feasibility of using recycled coarse aggregate obtained from destroyed buildings using well water instead of potable water in this city. The effects on concrete and mortar would show whether it is possible and appropriate to use these materials in new construction.

\section{Mix proportions and specimen preparation}

This part deals with the various materials used in the present investigation, their choice, grading, and relevant properties.

Ordinary Portland cement with a fineness of $300 \mathrm{~m}^{2} / \mathrm{kg}$ was used (Iraqi Standard Specification IQS No. 5 [18]). Its chemical and physical properties are described in Table 1.

Natural brown sand was used as fine aggregate. Its specific gravity (2.63), \% absorption (1.5), and maximum size $(4.75 \mathrm{~mm}$, Fig. 1) were within the grading limits of BS.882 [19].

Natural rounded gravel with a maximum size of $19 \mathrm{~mm}$ obtained from Tigris River (Mosul, Iraq) was used (Table 2). The coarse aggregate was prepared within the limits of ASTM C33/C33 M [20] to have the same size range as recycled coarse aggregate (Figs. 2, 3, 4). The coarse recycled 
Table 1 Chemical analysis of the ordinary cement used

\begin{tabular}{lcllcl}
\hline $\begin{array}{l}\text { Chemical } \\
\text { composition }\end{array}$ & Value (\%) & $\begin{array}{l}\text { Standard (IQS, } \\
\text { No. 5, 2018) (\%) }\end{array}$ & Chemical composition & Value (\%) & $\begin{array}{l}\text { Standard (IQS, } \\
\text { No. 5, 2018) } \\
(\%)\end{array}$ \\
\hline $\mathrm{SiO}_{2}$ & 18.0 & $\ldots$. & $\mathrm{C}_{3} \mathrm{~A}$ & 5.62 & $\ldots$. \\
$\mathrm{AL}_{2} \mathrm{O}_{3}$ & 4.52 & $\ldots$. & $\mathrm{C}_{4} \mathrm{AF}$ & 12.36 & $\ldots$. \\
$\mathrm{Fe}_{2} \mathrm{O}_{3}$ & 4.27 & $\ldots$. & Solid solution & 15.58 & $\ldots$. \\
$\mathrm{CaO}$ & 62.7 & $\ldots$. & L.S.F. & 0.97 & $0.66-1.02$ \\
$\mathrm{MgO}$ & 4.24 & $(5.0) \mathrm{max}$ & Free lime & 0.58 & $\ldots$. \\
$\mathrm{SO}_{3}$ & 1.86 & $(2.8) \mathrm{max}$ & Loss on ignition & 1.67 & $(4.0) \max$ \\
$\mathrm{C}_{3} \mathrm{~S}$ & 69.7 & $\ldots$. & Insoluble residue & 0.97 & $(1.5) \max$ \\
$\mathrm{C}_{2} \mathrm{~S}$ & 2.31 & $\ldots$. & & & \\
\hline
\end{tabular}

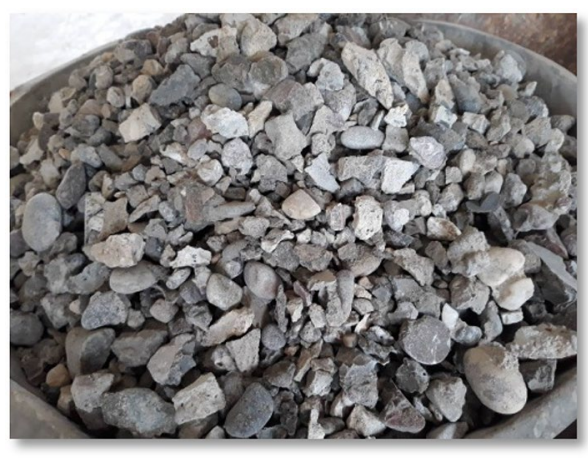

Fig. 3 Recycled coarse aggregate

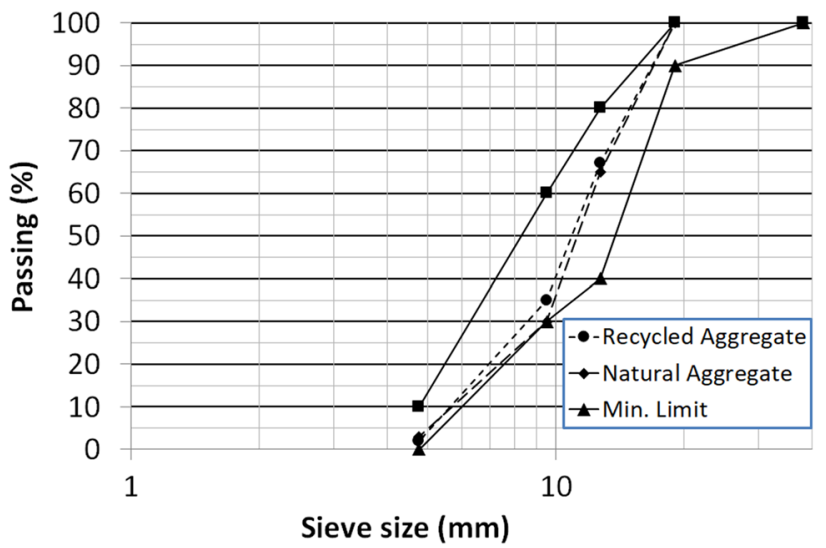

Fig. 4 Grading of coarse aggregate

aggregate was obtained by cleaning and crushing the parts of a destroyed 20-year-old building at Mosul University.

For mixing design and curing of concrete samples, two types of water were used: potable water and well water from the Mosul University campus. A chemical analysis of the well water and comparison with the standard limits of ASTM C94/C94 M [21] is provided in Table 3.

The concrete mix proportion was chosen among trial mixes. All mixes were free from chemical admixtures. The

Fig. 2 Natural coarse aggregate 
mix proportion was 1:1.88:2.16/0.45 with a cement content of $390 \mathrm{~kg} / \mathrm{m}^{3}$. Four different concrete mixtures were used in the experimental program of this study:

1. Reference concrete mix with natural coarse aggregate and potable water (NCA-PW)

2. Concrete mix with natural coarse aggregate and well water (NCA-WW)

3. Concrete mix with recycled coarse aggregate and potable water (RCA-PW)

4. Recycled coarse aggregate and well water (RCA-WW)

Table 3 Chemical analysis of well water

\begin{tabular}{lcc}
\hline $\begin{array}{l}\text { Chemical compounds } \\
(\mathrm{mg} / \mathrm{L})\end{array}$ & $\begin{array}{l}\text { ASTM (C 94) Limits } \\
\text { (maximum concentration, } \\
\text { ppm) }\end{array}$ & Well water \\
\hline Chloride, as Cl & 500 & 205 \\
Sulfate, as $\mathrm{SO}_{4}$ & 3000 & 1000 \\
Alkalis, as $\mathrm{Na}_{2} \mathrm{O}+0.658 \mathrm{~K}_{2} \mathrm{O}$ & 600 & 280 \\
Calcium, as Ca & & 450 \\
Total solids & 50,000 & 1200 \\
Magnesium, as Mg & & 16.8 \\
Total dissolved solids & & 1500 \\
Conductivity & & 2240 \\
pH & & 7.4 \\
\hline
\end{tabular}

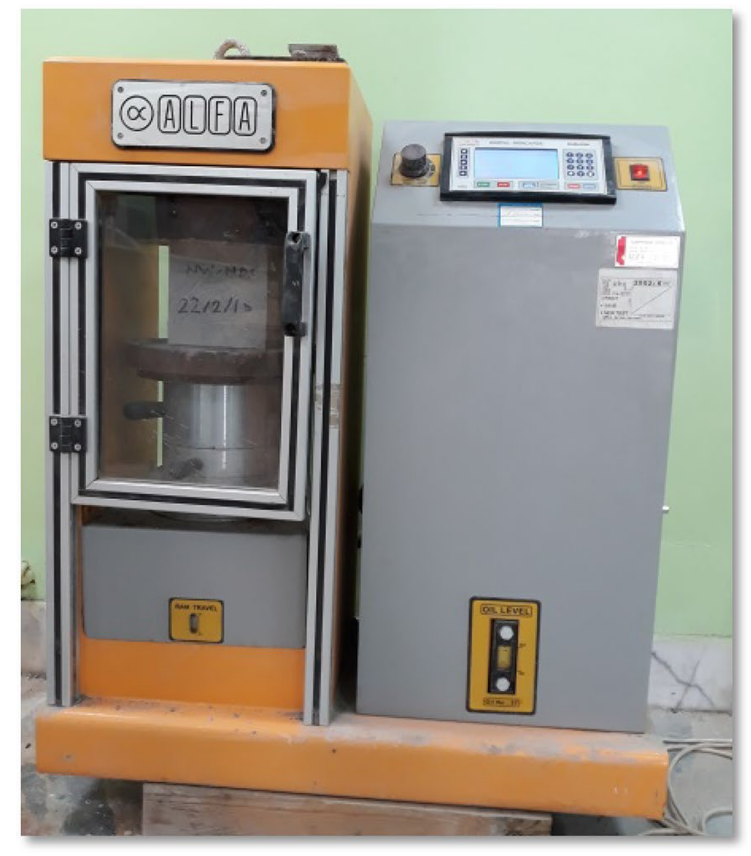

(a)
The slump test [22] evaluates the workability or consistency of fresh mixes. The slump was fixed at $100 \mathrm{~mm}$. About 10\% more water was used in the concrete made with recycled coarse aggregate than in the concrete with natural coarse aggregate to maintain the same slump value because of the higher water absorption of recycled coarse aggregate compared to natural aggregate [2].

The concrete mixtures were cast in molds and kept there for $24 \mathrm{~h}$, and then cured with water for 28 days. Standard cubes with dimensions of $150 \mathrm{~mm}^{3}$ were used to determine the compressive strength of the concrete. For each concrete mixture, three cubes were tested after curing for 28 days. The compressive strength of the specimens was tested according to BS1881: Part 116 [23]. Similarly, the split tensile test was conducted on three samples, all $100 \times 200 \mathrm{~mm}$ cylinders, and the flexural strength test was conducted on $100 \times 100 \times 500 \mathrm{~mm}$ beams. The splitting tensile strength and the flexure strength were tested according to the ASTM C496/C496 M [24] and ASTM C293/ C293 M [25] specifications, respectively (Fig. 5).

\section{Results}

\subsection{Effect of well water on compressive strength of mortar}

The compressive strength of mortar prepared using well water decreased over time (Fig. 6).

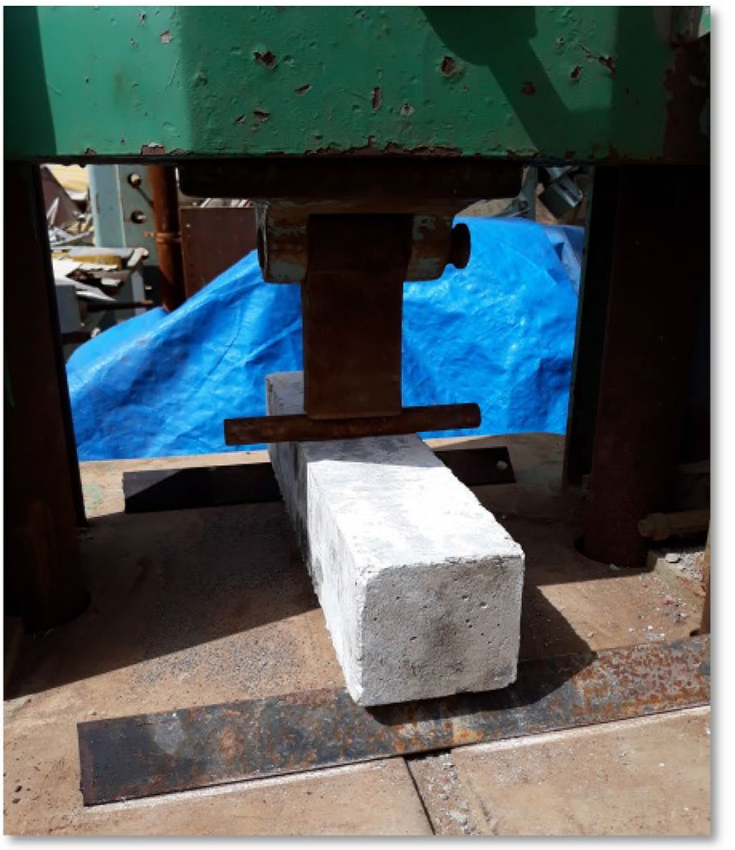

(b)

Fig. 5 Experimental setup for $\mathbf{a}$ compression and $\mathbf{b}$ flexural test 
Fig. 6 Compressive strength of mortar prepared with potable (square) and well (diamond) water after 3 and 7 days

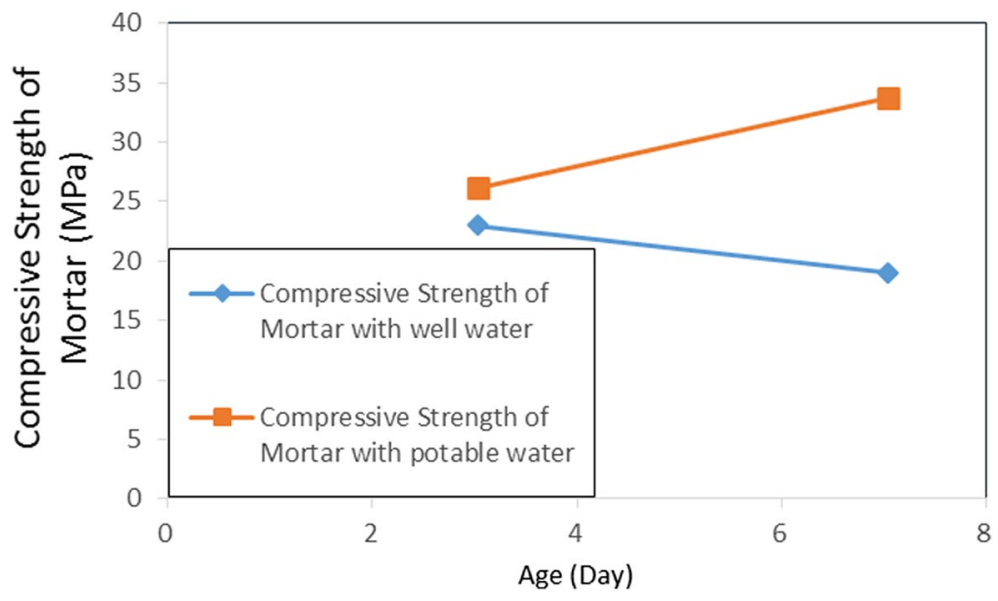

\subsection{Effect of well water and recycled aggregate on mechanical properties of concrete}

The results for compressive, flexural, and splitting strength of the various concrete mixtures are provided in Table 4. These values represent the average of results for three specimens for each test.

\subsubsection{Compressive strength test}

The compressive strength of concrete was lower for recycled aggregate [26] and well water. It can be seen from the data in Table 4 and Fig. 7 that the decrease in compressive strength was about $19 \%$, a value noted with recycled aggregate and curing with well water (RCA-WW), as compared to the control group (NCA-PW).

\subsubsection{Split tensile strength results}

The split tensile strength of RCA-PW was the highest, 5.6 $\mathrm{MPa}$, while that of NCA-PW was 4.7 MPa. This result shows that the use of recycled aggregate increased the split tensile strength of concrete (Fig. 8).

\subsubsection{Flexural strength results}

The results of flexural strength tests are illustrated in Table 4 and Fig. 9. The flexural strength of RCA-PW had the largest value, $10.1 \mathrm{MPa}$, while the flexural strength of NCA-PW was 9.3 MPa. These values show the same trend observed for splitting strength.

\subsubsection{Modulus of elasticity of concrete}

The modulus of elasticity of the concrete mixes is provided in Fig. 10. The value is highest for NCA-WW and lowest for RCA-WW; this makes sense because elasticity depends on the compressive strength.
Table 4 Summary of test results

\begin{tabular}{llcll}
\hline $\begin{array}{l}\text { Concrete } \\
\text { mix }\end{array}$ & $\begin{array}{l}\text { Com- } \\
\text { pressive } \\
\text { strength } \\
(\mathrm{MPa})\end{array}$ & $\begin{array}{l}\text { Flexural } \\
\text { strength } \\
(\mathrm{MPa})\end{array}$ & $\begin{array}{l}\text { Splitting } \\
\text { strength } \\
(\mathrm{MPa})\end{array}$ & $\begin{array}{l}\text { Modulus of } \\
\text { elasticity } \\
(\mathrm{MPa})\end{array}$ \\
\hline NCA-PW & 50.9 & 9.3 & 4.7 & 29965 \\
NCA-WW & 47.1 & 9.1 & 4.5 & 28825 \\
RCA-PW & 45.6 & 10.1 & 5.6 & 28362 \\
RCA-WW & 41.0 & 9.45 & 5.3 & 26893 \\
\hline
\end{tabular}

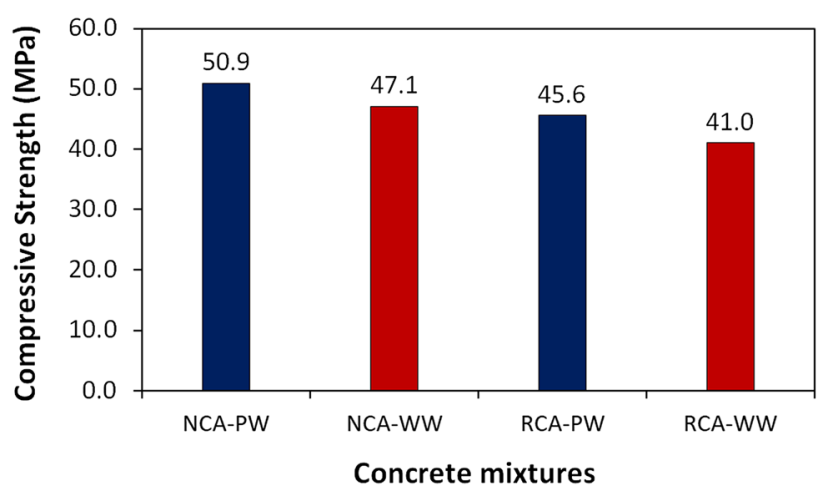

Fig. 7 Compressive strength of the concrete mixes

\subsection{Effect of water type on the mechanical properties of concrete}

Concrete made with natural coarse aggregate and mixed and cured with well water exhibited compressive strength about $7.5 \%$ lower than concrete mixed and cured with potable water. The losses in flexural and splitting strength were approximately $2.2 \%$ and $4.2 \%$, respectively, when using well water, with a decrease in modulus of elasticity of $3.8 \%$ for the same mixes. These reductions are probably due to the effect of impurities in the well water, e.g., 


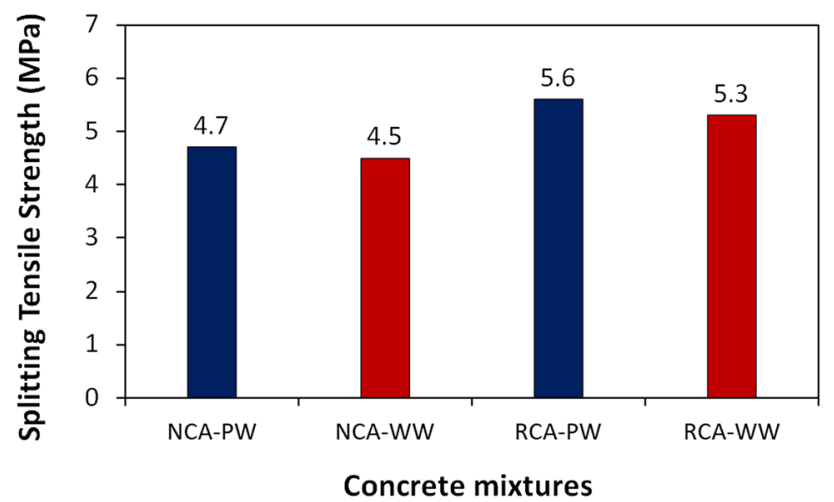

Fig. 8 Split tensile strength of the concrete mixes

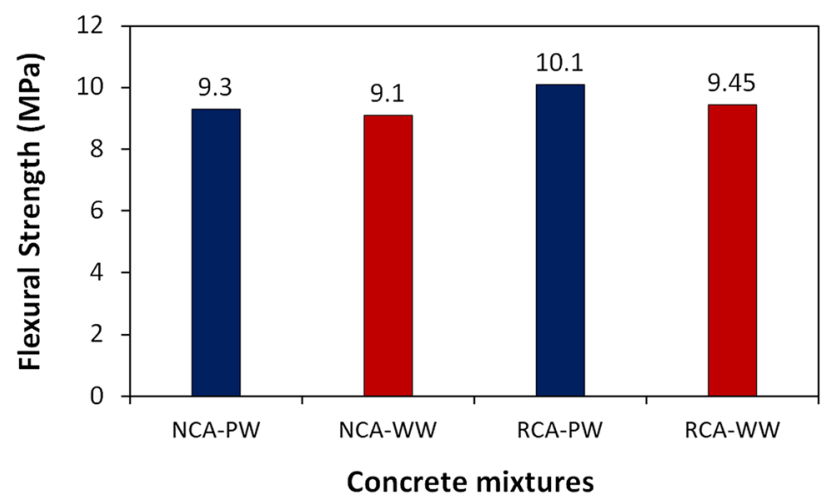

Fig. 9 Flexural strength of the concrete mixes

compounds such as calcium, iron, sodium, and other inorganic salts, these may reduce the initial strength of concrete, and in some cases, no strength can be achieved. In addition, the presence of acid, alkali, and sanitary sewage reduced the strength of concrete.

Concrete containing recycled aggregate and cured by well water exhibited compressive strength about $10 \%$ lower than that of concrete cured by potable water and containing recycled aggregate. Tests showed that the flexure, splitting, and modulus of elasticity for concrete prepared using well water were lower by $6.4,5.4$, and $5.1 \%$, respectively.

Based on the results, the use of well water is permissible for mixing concrete, especially after making the typical analysis and comparison with the limits of specifications. The water naturally contains a wide range of dissolved chemicals including chlorides, sulfates, alkalis, etc., and when these compounds within the standard limit, it may be harmless or even beneficial when using in mixing in plain concrete.

\subsection{Effect of recycled aggregate on mechanical properties of concrete}

When natural coarse aggregate was replaced by the recycled coarse aggregate in cement mixed and cured with potable water, decreases of $10.4 \%$ in compressive strength and $5.3 \%$ in modulus of elasticity were observed (Table 4). While decreasing about $12.9 \%$ and $6.7 \%$ in compressive strength and modulus of elasticity respectively of concrete specimens when they have been immersed in well water.

Generally, the results in Table 4 demonstrate a notable increase in flexural and tensile strength when recycled aggregate was used, regardless of whether the concrete was cured using potable or well water. When replacing natural coarse aggregate with recycled coarse aggregate and mixing and curing with potable water, the splitting and flexural tensile strengths were $19 \%$ and $8.6 \%$ higher, respectively.

The experimental results show that concrete made with recycled concrete aggregate has high bonding strength between the coarse aggregate and the surrounding paste. This may be due to the angularity of the coarse aggregate and the residual cementation on the surface of the recycled aggregate. This might explain the increase in flexural and splitting tensile strength when low percentages of recycled coarse aggregates are used in the concrete mix.
Fig. 10 Modulus of elasticity for the concrete mixes

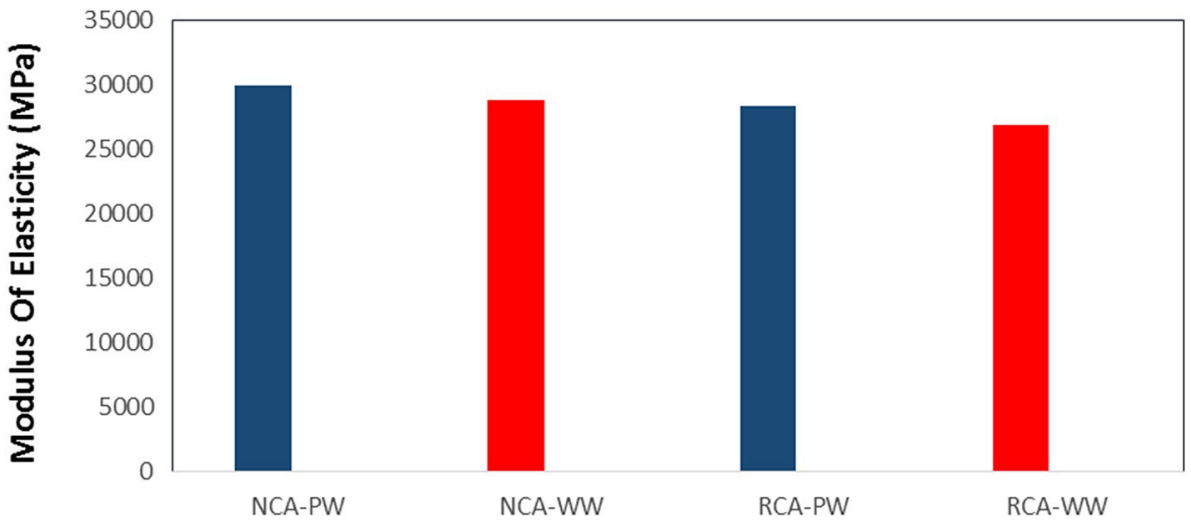




\section{Conclusions}

1. The chemical composition of the well water that is used in this study generally differed from that of potable water, but still fell within the standard limits specified by the ASTM C94/C94 M [21]. The high concentrations of some substances could raise concerns about the potential for corrosion and sulfate attack in reinforced concrete structures.

2. About $10 \%$ more water was required in concrete made with recycled coarse aggregate than in the concrete with natural coarse aggregate to maintain the same slump. This increase in water content affects strength. It is believed that if admixtures were used to increase workability, while maintaining the same amount of water in the two concretes, then the recycled concrete would have had higher strength than was observed. The addition of extra mixing water is known to weaken the macro properties of concrete materials because of the higher water-cement ratio $[27,28]$.

3. The percentage loss in compressive strength due to the use of recycled aggregate is more substantial in concrete mixes cured with well water than those cured using potable water.

4. The use of well water decreases the compressive strength of mortar over time.

5. Recycled concrete aggregate can be effectively used as a replacement aggregate.

6. However, further study should be conducted to investigate the effect of well water on the durability of concrete, since this water may contain substances that may adversely affect the concrete after prolonged exposure.

Acknowledgements The authors are very grateful to the staff of construction materials testing laboratory of Mosul University for their cooperation to complete this work.

\section{Compliance with ethical standards}

Conflict of interest The authors declare that they have no conflict of interest.

\section{References}

1. Harilal M, Rathish VR, Anandkumar B, George RP, Sheikh Mohammed MSH, Philip J, Amarendra G (2019) High-performance green concrete (HPGC) with improved strength and chloride ion penetration resistance by synergistic action of fly ash, nanoparticles and corrosion inhibitor. Constr Build Mater 198:299-312

2. Princigallo $A$ (2018) Effective water in concrete with recycled aggregate. ACI Mater J 115(6):845-854
3. Surya M, Kanta Rao VVL, Lakshmy P (2015) Mechanical, durability, and time-dependent properties of recycled aggregate concrete with fly ash. ACI Mater J 112(5):653-662

4. Corinaldesi V (2010) Mechanical and elastic behaviour of concretes made of recycled-concrete coarse aggregates. Constr Build Mater 24:1616-1620

5. Gluzhge PJ (1946) The work of scientific research institute. Gidrotekhnicheskoyem Stroitel'stvo 4:27-28 (only available in Russian)

6. Hansen TC, Hedegard SE (1984) Properties of recycled aggregate concrete as affected by admixtures in original concretes. $\mathrm{ACl} J$ 81(1):21-26

7. Rifat R, Salah T, Ali B, Hani B (2007) Properties of recycled aggregate in concrete and road pavement applications. Islam Univ J $15: 247-264$

8. Al-Sulayfani BJ, Aljubory NH, Al-Luhybi AS (2011) Design chart of concrete containing recycled coarse aggregate. Al-Rafidain Eng J 19(5):1-9

9. Sheen YN, Wang HY, Juang YP, Le DH (2013) Assessment on the engineering properties of ready-mixed concrete using recycled aggregates. Constr Build Mater 45:298-305

10. Ramadevi K, Chitra R (2017) Concrete using recycled aggregates. Int J Civ Eng Technol 8(9):413-419

11. Cebeci OZ, Saatci AM (1989) Domestic sewage as mixing water in concrete. ACI Mater J 86(5):503-506

12. Use of Recycled Water in Concrete Production (2007) Cement Concrete and Aggregates Australia (CCAA). www.ccaa.com.au, pp 1-27

13. Ghorab HY, Hilal MS, Anter A (1990) Effect of mixing and curing water on the behavior of cement pastes and concrete. Part: 2 . Cem Concr Res 20:69-72

14. Nevillee (1994) Properties of concrete. Longman Scientific \& Technical publication, Signapore, pp 10-87

15. Al-Amoudi OSB (1995) Durability of reinforced concrete in aggressive sabkha environments. ACl Mater J 92(3): 236-245

16. Hassan IH, Abdul-Kareem OM, Shihab AY (2014) Effect of using well water as mixing water in concrete. Al-Rafidain Eng $\mathrm{J}$ 22(5):17-28

17. Kucche KJ, Jamkar SS, Sadgir PA (2015) Quality of water for making concrete: a review of literature". Int J Sci Res Publ 5(1): $1-10$

18. Iraqi Standard Specification No. 5 (2018) Properties of ordinary Portland cement, Iraq

19. BSI BS-882 (1992) Specification for aggregates from natural sources for concrete. BSI, London

20. ASTM C33, C33M (2018) Standard specification for concrete aggregate. ASTM International, West Conshohocken

21. ASTM C94, C94M (2017) Standard specification for ready-mixed concrete. ASTM International, West Conshohocken

22. ASTM C143, C143M (2015) Standard test method for slump of hydraulic-cement concrete. ASTM International, West Conshohocken

23. BSI BS 1881, Part 116 (1983) Testing concrete, method for determination of compressive strength of concrete cubes. BSI, London

24. ASTM C496, C496M (2017) Standard test method for splitting tensile strength of cylindrical concrete specimens. ASTM International, West Conshohocken

25. ASTM C293, C293M (2016) Standard test method for flexural strength of concrete (using simple beam with center-point loading). ASTM International, West Conshohocken

26. Murali G, Vivek Vardhen CM, Rajan Gabriela, Janani GJ, Shifu Jajan N, Ramya Sri R (2012) Experimental study on recycled aggregate concrete. Int J Eng Res Appl 2(2):407-410 
27. Zhao Y, Zeng W, Zhang H (2017) Properties of recycled aggregate concrete with different water control methods. Constr Build Mater 152:539-546

28. Gonzalez-Corominas A, Etxeberria M, Poon C (2017) Influence of the quality of recycled aggregates on the mechanical and durability properties of high performance concrete. Waste Biomass Valorization 8(5):1421-1432

Publisher's Note Springer Nature remains neutral with regard to jurisdictional claims in published maps and institutional affiliations. 